\title{
ANALISIS USAHA TERNAK AYAM BROILER DI KABUPATEN KARANGANYAR
}

\author{
*Himmah Nur Hayati, Minar Ferichani, Isti Khomah \\ Program Studi Agribisnis, Fakultas Pertanian, Universitas Sebelas Maret, Surakarta \\ *Corresponding author: himmah056@ student.uns.ac.id
}

\begin{abstract}
This research is aimed to analyze cost, revenue, profit, profitability, Break Event Point, business efficiency and the risks of broiler chicken farming in Jumantono District, Karanganyar Regency. This research was conducted in June-July 2018. Data used was one production period (35 days). The basic method in this study is descriptive analytical method and using case study techniques. Determination of the location of the study was carried out by purposive (intentional), namely in the District of Jumantono, Karanganyar Regency. The respondents were taken by quota sampling method as many as 30 respondents. The types and and sources of data consist of primary data and secondary data. Data collection techniques are carried out by interview, observation and recording. The results showed that the average total cost of broiler chicken farming was IDR 124,291,091 and the average income was IDR 165,114,558, - so that the profits obtained were IDR 40,823,467. Broiler chicken farms in Jumantono District, Karanganyar Regency benefit from a profitability rate of $32.85 \%$. Nliai $R / C$ ratio or broiler chicken business efficiency of 1.32. BEP products from broiler chicken farms amounted to $1,665.1 \mathrm{~kg}$, BEP sales amounted to IDR 29,391,635, and BEP prices were IDR 13,489 / kg. Broiler chicken farming in Jumantono District, Karanganyar Regency has a $C V$ value of $\leq 0.5$ or $L \geq 0$ so that it avoids the risk, because the lower limit of profit $(L)$ shows a positive value (+).
\end{abstract}

Keywords: Broiler Chicken, Business Analysis, Livestock Business.

\begin{abstract}
Abstrak: Penelitian ini bertujuan untuk menganalisis besarnya biaya, penerimaan, keuntungan, profitabilitas, Break Event Point, efisiensi usaha serta risiko pada usaha ternak ayam broiler di Kecamatan Jumantono, Kabupaten Karanganyar. Penelitian ini dilakukan pada bulan Juni-Juli 2018. Data yang digunakan yaitu satu periode produksi (35 hari). Metode dasar pada penelitian ini adalah metode deskriptif analitik dan menggunakan teknik studi kasus. Penentuan lokasi penelitian dilakukan secara purposive (sengaja) yaitu di Kecamatan Jumantono, Kabupaten Karanganyar. Pengambilan responden dilakukan dengan metode kuota sampling sebanyak 30 responden. Jenis dan sumber data terdiri atas data primer dan data sekunder. Teknik pengumpulan data dilakukan dengan wawancara, observasi dan pencatatan. Hasil penelitian menunjukkan bahwa rata-rata biaya total dari usaha ternak ayam broiler sebesar Rp 124.291.091,- dan penerimaan rata-rata sebesar Rp 165.114.558,sehingga keuntungan yang diperoleh sebesar Rp 40.823.467,-. Usaha ternak ayam broiler di Kecamatan Jumantono Kabupaten Karanganyar memperoleh keuntungan dengan tingkat profitabilitas 32,85\%. Nliai R/C rasio atau efisiensi usaha ternak ayam broiler sebesar 1,32. BEP produk dari usaha ternak ayam broiler sebesar $1.665,1 \mathrm{~kg}$, BEP penjualan sebesar Rp 29.391.635,- dan BEP harga sebesar Rp 13.489 per kg. Usaha ternak ayam broiler di Kecamatan Jumantono Kabupaten Karanganyar memiliki nilai $\mathrm{CV} \leq 0,5$ atau $\mathrm{L} \geq 0$ sehingga terhindar dari resiko, karena batas bawah keuntungan (L) menunjukkan nilai positif (+).
\end{abstract}

Kata Kunci : Ayam Broiler, Analisis Usaha, Usaha Ternak. 


\section{PENDAHULUAN}

Indonesia merupakan wilayah yang memiliki kekayaan sumber daya alam yang melimpah. Kekayaan sumberdaya alam tersebut menjadikan Indonesia dikenal sebagai negara agraris. Peternakan sebagai salah satu subsektor pertanian memiliki peranan yang penting dalam pembangunan strategis diantaranya adalah peternakan sebagai penyedia pangan terutama dalam memenuhi kebutuhan rakyat akan protein hewani, peternakan sebagai sumber pendapatan dan kesempatan kerja, sebagai usaha pertanian yang berkelanjutan dan perbaikan lingkungan hidup (Wandi, 2015).

Ayam broiler merupakan salah satu komoditas ternak yang berperan sebagai sumber protein hewani. Menurut Loen (2017) usaha peternakan ayam broiler lebih menguntungkan karena ayam broiler memiliki banyak nilai lebih dibandingkan beternak jenis unggas yang lain. Salah satu keuntungannya yaitu masa pemeliharaan yang relatif singkat (umur panen 30-35 hari) sehingga peternak dapat segera meraup keuntungan dan bisa memutar modal dengan cepat, berbeda dengan beternak ayam kampung atau ayam petelur yang harus menunggu hingga 6 bulan lamanya baru bisa di panen.

Badan Pusat Statistik (Susenas 2017) mengatakan bahwa konsumsi protein tertinggi jenis daging oleh masyarakat Indonesia adalah daging ayam broiler, konsumsi daging ayam broiler penduduk di Indonesia selalu meningkat mulai dari tahun 2012 sampai tahun 2016. Konsumsi daging ayam broiler sangat erat kaitannya dengan harga karena masyarakat memiliki kendala pendapatan dalam memenuhi kebutuhannya Antriyandarti (2012). Kabupaten Karanganyar adalah salah satu Kabupaten di Propinsi Jawa Tengah yang membudidayakan ayam broiler. Daerah yang cocok untuk usaha ternak berupa area lahan tegalan dan cukup jauh dari perkotaan sehingga membuat sebagian besar penduduknya melakukan usaha ternak ayam broiler.

Berdasarkan uraian di atas maka tujuan dari penelitian ini adalah: 1) Untuk mengetahui besarnya biaya, penerimaan, keuntungan, profitabilitas serta break even point (BEP) produksi $(\mathrm{kg})$ dan break even point (BEP) harga (Rp) dari usaha ternak ayam broiler di Kabupaten Karanganyar; 2) untuk mengetahui efisiensi usaha ternak ayam broiler di Kabupaten Karanganyar; 3) Untuk mengetahui risiko usaha ternak ayam broiler di Kabupaten Karanganyar.

\section{METODE PENELITIAN}

\section{Metode Dasar Penelitian}

Metode dasar penelitian yang digunakan dalam penelitian ini adalah metode deskriptif analitis melalui survei dan observasi. Metode deskriptis merupakan metode penelitian yang digunakan untuk menggambarkan fenomena yang terjadi saat ini maupun pada waktu lampau. Metode deskriptif analitis merupakan metode penelitian yang memusatkan diri pada pemecahan masalah-masalah yang ada pada masa sekarang, pada masalah-masalah yang aktual, dimana data yang dikumpulkan mula-mula disusun, dijelaskan dan kemudian dianalisis (Surakhmad, 2001).

\section{Metode Penentuan Lokasi}

Penentuan lokasi penelitian ini dilakukan secara purposive (sengaja), yaitu berdasarkan pertimbangan-pertimbangan tertentu sesuai dengan tujuan penelitian (Singarimbun dan Effendi, 1995). Purposive menunjukkan bahwa teknik ini digunakan untuk mencapai tujuan tertentu (Soekartawi, 1995). Lokasi penelitian adalah di Kabupaten Karanganyar khususnya Kecamatan Jumantono. Alasan penentuan lokasi yaitu karena di Kecamatan tersebut terdapat paling banyak populasi ayam broiler.

\section{Metode Pengambilan Responden}

Menurut Singarimbun dan Effendi (1995), bila data dianalisis dengan statistik parametrik maka jumlah data sampel harus besar, karena nilainilai yang diperoleh distribusinya harus mengikuti distribusi normal. Sampel yang tergolong sampel besar yang distribusinya normal adalah sampel yang jumlahnya $\geq 30$ yang diambil secara non-probality sampling. Dalam penelitian ini jumlah sampel yang digunakan sebanyak 30 peternak.

Pemilihan sampel peternak ayam broiler dilakukan dengan teknik sampling kuota. Teknik sampling kuota yaitu teknik untuk menentukan sampel yang berasal dari populasi yang memiliki ciri-ciri tertentu sampai jumlah kuota yang diinginkan. Dalam penelitian ini sampel adalah peternak ayam broiler dengan 
ciri-ciri memiliki populasi per siklus yaitu antara 3500 sampai 7000 ekor.

\section{Metode Analisis Data}

Biaya tetap adalah biaya yang tidak dipengaruhi oleh naik turunnya produksi yang dihasilkan. Contohnya biaya tetap tenaga kerja luar keluarga, penyusutan alat, bunga modal. Dalam penelitian ini, peneliti menggunakan metode garis lurus (Straight line method) untuk menghitung penyusutan. Rumus menghitung penyusutan menurut Suratiyah (2015):

Penyusutan per tahun $=\frac{\text { harga barang-nilai sisa }}{\text { umur ekonomis }}$

Biaya variabel adalah biaya yang jumlah totalnya berubah sebanding dengan perubahan volume produksi. Biaya variabel per unit tetap dengan adanya perubahan volume produksi. Biaya Total adalah penjumlahan dari nilai total biaya tetap (TFC) dan nilai biaya variabel (TVC) yang digunakan dalam kegiatan budidaya ayam broiler selama 1 periode panen. $\mathrm{TC}=\mathrm{TFC}+\mathrm{TVC}$.

Besarnya penerimaan usaha ternak ayam broiler oleh peternak dapat diketahui dengan menggunakan rumus $\mathrm{TR}=\mathrm{Q} \times \mathrm{P}$ dimana $\mathrm{TR}=$ Penerimaan total usaha ternak ayam broiler ( $\mathrm{Rp} / \mathrm{Ha} / \mathrm{MT}), \mathrm{Q}=$ kuantitas produksi $(\mathrm{kg}), \mathrm{P}=$ harga ayam per $\mathrm{kg}(\mathrm{Rp} / \mathrm{kg})$.

Keuntungan usaha adalah selisih antara penerimaan total dengan biaya total dengan rumus $\pi=\mathrm{TR}-\mathrm{TC}$ dimana $\pi=$ keuntungan usaha ternak ayam broiler (Rp), $\mathrm{TR}=$ penerimaan total usaha ternak ayam broiler $(\mathrm{Rp}), \mathrm{TC}=$ Total biaya usaha ternak ayam broiler (Rp).

Untuk mengetahui nilai profitabilitas usaha adalah dengan membandingkan antara keuntungan usaha ternak yang diperoleh dengan total biaya yang telah dikeluarkan dan dikalikan $100 \%$ dengan rumus sebagai berikut:

$$
\text { Profitabilitas }=\frac{\pi}{T C} \times 100 \%
$$

Analisis Break Event Point adalah suatu teknik analisis untuk mempelajari hubungan antara biaya tetap, biaya variabel, keuntungan dan volume kegiatan. Untuk menghitung BEP menurut Suratiyah (2015) sebagai berikut:

1. Perhitungan Break Event Point atas dasar unit

$$
\operatorname{BEP}(\mathrm{Q})=\frac{F C}{\mathrm{P}-A V C} \times 1 \mathrm{~kg}
$$

2. Perhitungan Break Event Point atas dasar jumlah penjualan $(\mathrm{Rp})$

$$
\text { BEP penjualan }(\mathrm{Rp})=\frac{F C}{1-\frac{A V C}{P}}
$$

3. BEP harga $=\frac{T C}{Y}$

Keterangan :

$\mathrm{FC}=$ Fixed Cost (Biaya tetap $)$

$\mathrm{VC}=$ Variabel Cost (Biaya variabel)

$\mathrm{P}$ = Harga jual per ekor ayam

$\mathrm{Q}=$ Jumlah Hasil produksi

$\mathrm{Y}=$ Penerimaan

Efisiensi usaha ternak dapat dihitung dengan membandingkan besarnya penerimaan usaha ternak dengan biaya yang digunakan untuk produksi yang secara matematis dapat dirumuskan sebagai berikut :

$\mathrm{R} / \mathrm{C}$ Rasio $=\frac{T R}{T C}$

$\mathrm{R} / \mathrm{C}>1$ berarti usaha ternak ayam broiler yang dijalankan sudah efisien.

$\mathrm{R} / \mathrm{C}=1$ berarti usaha ternak ayam broiler belum efisien atau baru mencapai kondisi impas.

$\mathrm{R} / \mathrm{C}<1$ berarti usaha ternak ayam broiler yang dijalankan tidak efisien.

Menurut Kadarsan (1995) untuk mengetahui resiko secara matematetis menggunakan rumus:

$\mathrm{CV}=\frac{V}{E}$

Keterangan :

$\mathrm{CV}=$ koefisien variasi usaha ternak ayam broiler

$\mathrm{V}$ = simpangan baku usaha ternak ayam broiler (Rp)

$\mathrm{E}=$ keuntungan rata-rata usaha ternak ayam broiler (Rp)

Sebelum mengukur koefisien variasi harus mencari keuntungan rata-rata usaha ternak ayam broiler dan simpangan bakunya, yang dirumuskan sebagai berikut :

$\mathrm{E}=\frac{\sum_{\mathrm{i}=1}^{\mathrm{n}} E i}{n}$

Keterangan :

$\mathrm{E}=$ keuntungan rata-rata usaha ternak ayam broiler (Rp)

$\mathrm{Ei}=$ keuntungan usaha yang diterima peternak ayam broiler $(\mathrm{Rp})$ 
$\mathrm{n}=$ jumlah peternak ayam broiler (orang)

Selanjutnya mencari simpangan baku dengan menggunakan metode analisis ragam karena simpangan baku merupakan akar dari ragam, yaitu :

$\mathrm{V}=\sqrt{v^{2}}$

Adapun dalam perhitungan analisis ragam dirumuskan sebagai berikut:

$\mathrm{V}^{2}=\frac{\sum_{i=1}^{n}(E i-E)^{2}}{n-1}$

Keterangan :

$\mathrm{V}^{2}=$ ragam

$\mathrm{n}=$ jumlah peternak ayam broiler (orang)

$\mathrm{E}=$ keuntungan rata-rata usaha ternak ayam broiler (Rp)

Ei $=$ keuntungan usaha ternak ayam broiler yang diterima peternak (Rp)

Untuk mengetahui batas bawah keuntungan usaha ternak ayam broiler digunakan rumus:

$\mathrm{L}=\mathrm{E}-2 \mathrm{~V}$

Keterangan :

$\mathrm{L}=$ batas bawah keuntungan usaha ternak ayam broiler $(\mathrm{Rp})$

$\mathrm{E}=$ keuntungan rata-rata usaha ternak ayam broiler (Rp)

$\mathrm{V}=$ simpangan baku usaha ternak ayam broiler $(\mathrm{Rp})$

Semakin besar nilai CV menunjukkan bahwa risiko usaha yang harus ditanggung produsen semakin besar. Kriteria yang digunakan adalah apabila nilai $\mathrm{CV} \leq 0,5$ atau $\mathrm{L}$ $\geq 0$ menyatakan bahwa peternak ayam broiler akan selalu terhindar dari kerugian. Dan apabila nilai $\mathrm{CV}>0,5$ atau $\mathrm{L}<0$ berarti ada peluang kerugian yang akan diderita oleh peternak (Hernanto, 1993).

\section{HASIL DAN PEMBAHASAN}

Jumlah peternak yang dijadikan sampel adalah 30 orang dengan rata-rata lama mengusahakan 6-10 tahun. Rata-rata umur peternak berada pada golongan usia produktif yaitu 28-55 tahun. sehingga petani memiliki kemauan dan kemampuan yang tinggi dalam kegiatan usaha ternak ayam broiler. Rata-rata pendidikan terakhir peternak adalah SMA/SMK sederajat. Rata-rata jumlah anggota dalam keluarga yaitu
4 orang dan hanya 1 orang yang aktif dalam kegiatan usaha ternak ayam broiler. Sedangkan rata-rata jumlah populasi ayam yang diusahakan adalah 5070 ekor.

Sarana produksi merupakan sarana yang dibutuhkan dalam usaha ternak ayam broiler agar kegiatan usaha ternak dapat berjalan dengan baik dan dapat menghasilkan produksi sesuai dengan harapan. Sarana produksi yang dibutuhkan dalam usaha ternak ayam broiler adalah bibit (DOC), pakan, vaksin/obat-obatan, sekam, gas LPG dan tenaga kerja. Tenaga kerja merupakan jenis input atau masukan lain yang memiliki peranan penting dalam keberlangsungan usaha ternak ayam broiler. Tenaga kerja dapat berasal dari dalam keluarga maupun dari luar keluarga. Tenaga kerja berperan dalam semua tahapan usaha ternak mulai dari persiapan kandang, pemeliharaan ayam hingga pemanenan.

Peralatan merupakan salah satu unsur penting dalam usaha ternak ayam broiler. Peralatan dapat menunjang kegiatan usaha ternak ayam broiler. Peralatan yang digunakan oleh peternak dalam usaha ternak ayam broiler diantaranya adalah sprayer, tempat pakan, tempat minum, kandang, gasolek (alat pemanas), drum penampung air, chick guard, kipas angin, dan termometer. Alat-alat yang digunakan dalam usaha ternak ayam broiler dirinci pada Tabel 1 .

Tabel 1. Rata-rata Penggunaan Peralatan pada Usaha Ternak Ayam Broiler di Kecamatan Jumantono Kabupaten Karanganyar, Juni-Juli 2018

\begin{tabular}{|c|c|c|}
\hline No. & Jenis Peralatan & Jumlah(unit) \\
\hline & Kandang & 1 \\
\hline & Tempat Pakam & 143 \\
\hline & Tempat Minum & 95 \\
\hline & Kipas angin/blower & 5 \\
\hline & Gasolek/alat pemanas & 8 \\
\hline & Sprayer & 1 \\
\hline & Tirai & 4 \\
\hline & Drum penampung air & 3 \\
\hline & Timbangan & 2 \\
\hline & Termometer & 2 \\
\hline & Chick Guard & 16 \\
\hline
\end{tabular}

Sumber: Analisis Data Primer (2018)

Tabel 1 menunjukkan rata-rata penggunaan peralatan pada usaha ternak ayam broiler di Kecamatan Jumantono Kabupaten Karanganyar. Alat-alat yang digunakan untuk 
usaha ternak ayam broiler meliputi: kandang, tempat pakan, tempat minum, kipas angin, gasolek, sprayer, tirai, drum penampung air/toren, timbangan, termometer, dan chick guard. Semua alat yang digunakan harus dibersihkan ketika memasuki awal pemeliharaan. Alat-alat tersebut memiliki umur ekonomis yang berbeda-beda sehingga menimbulkan biaya penusutan alat. Rata-rata biaya yang dikeluarkan untuk usaha ternak ayam broiler dapat dilihat secara lebih rinci pada Tabel 2.

Tabel 2. Rata-Rata Biaya Usaha Ternak Ayam Broiler Per Siklus Panen di Kecamatan Jumantono Kabupaten Karangnyar, JuniJuli 2018

\begin{tabular}{llr}
\hline No. & Uraian & \multicolumn{1}{l}{$\begin{array}{l}\text { Rata-rata } \\
\text { Biaya }\end{array}$} \\
\hline $1 . \quad$ Biaya Tetap (TFC) & 1.156 .927 \\
& Penyusutan Peralatan & 1.448 .433 \\
& Bunga Modal & 500.000 \\
& Biaya Listrik & 3.500 .000 \\
& Biaya Tenaga Kerja & 2.500 .000 \\
& Biaya Sewa Kandang & 6.047 \\
& Pajak PBB & 9.111 .407 \\
2. & Bimlah & 32.035 .000 \\
& Daya Old Chick (DOC) & 16.046 .833 \\
& Pakan starter & 64.466 .666 \\
& Pakan finisher & 1.470 .750 \\
& Vaksin dan obat-obatan & 465.333 \\
& Sekam & 695.100 \\
& Gas LPG & 115.179 .684 \\
& Jumlah & \\
3. & Biaya Total (TC) & 124.291 .091 \\
& Biaya Tetap + Biaya & \\
\hline
\end{tabular}

Sumber: Analisis Data Primer (2018)

Tabel 2 menunjukkan rata-rata biaya usaha ternak ayam broiler di Kecamatan Jumantono Kabupaten Karanganyar. Biaya tetap (TFC) terdiri dari penyusutan peralatan, bunga modal, biaya listrik, biaya tenaga kerja, biaya sewa kandang, dan pajak PBB dengan total biaya Rp 9.111.407. biaya variabel (TVC) terdiri dari Day Old Chick (DOC), pakan starter, pakan finisher, vaksin dan obat-batan, sekam dan gas LPG dengan total biaya Tp 115.179.684. biaya total merupakan penjumlahan dari biaya tetap dan biaya variabel sebesar Rp 124.291.091.
Tabel 3. Rata-rata Penerimaan Usaha Ternak Ayam Broiler di Kecamatan Jumantono Kabupaten Karangnyar, Juni-Juli 2018

\begin{tabular}{llll}
\hline Produk & $\begin{array}{l}\text { Rata-rata } \\
\text { kuantitas } \\
(\mathrm{kg})\end{array}$ & $\begin{array}{l}\text { Harga } \\
(\mathrm{Rp})\end{array}$ & $\begin{array}{l}\text { Penerimaan } \\
{[\mathrm{Px}]}\end{array}$ \\
& {$[\mathrm{Q}]$} & & \\
\hline $\begin{array}{l}\text { Daging } \\
\text { ayam }\end{array}$ & $9.214,38$ & 17.971 & 165.114 .558 \\
\hline Sumber: Analisis Data Primer (2018) &
\end{tabular}

Tabel 3 menunjukkan rata-rata penerimaan usaha ternak ayam broiler di Kecamatan Jumantono Kabupaten Karangnyar. Penerimaan diperoleh dari hasil perkalian kuantitas ayam yang dihasilkan (dalam kilogram) dan harga (Rupiah) sehingga penerimaan peternak sebesar Rp 165.114.558.

Tabel 4. Rata-rata Keuntungan Usaha Ternak Ayam Broiler di Kecamatan Jumantono Kabupaten Karanganyar, Juni-Juli 2018

\begin{tabular}{llr}
\hline No. & Uraian & \multicolumn{1}{l}{$\begin{array}{l}\text { Rata-rata } \\
\text { (Rp/siklus) }\end{array}$} \\
\hline 1 & Penerimaan (R) & 165.114 .558 \\
2 & Biaya Total (TC) & 124.291 .091 \\
& Keuntungan & 40.823 .467 \\
\hline
\end{tabular}

Sumber: Analisis Data Primer (2018)

Tabel 4 menunjukkan rata-rata keuntungan usaha ternak ayam broiler di Kecamatan Jumantono Kabupaten Karanganyar pada bulan Juni-Juli 2018. Keuntungan usaha diperoleh dari hasil penerimaan dikurangi biaya total sehinggan didapatkan keuntungan usaha ternak ayam broiler sebesar Rp 40.823.467 per siklus panen.

Tabel 5. Rata-rata Profitabilitas Usaha Ternak Ayam Broiler di Kecamatan Jumantono Kabupaten Karanganyar, Juni-Juli 2018

\begin{tabular}{llr}
\hline No. & Uraian & $\begin{array}{l}\text { Rata-rata } \\
\text { (Rp/siklus) }\end{array}$ \\
\hline 1 & Keuntungan & 40.823 .467 \\
2 & Biaya Total (TC) & 124.291 .091 \\
& Profitabilitas & 32,85 \\
\hline
\end{tabular}

Sumber: Analisis Data Primer (2018)

Tabel 5 menunjukkan rata-rata profitabilitas usaha ternak ayam broiler di Kecamatan Jumantoni Kabupaten Karanganyar pada Bulan Juni-Juli 2018. Rata-rata Profitabilitas usaha sebesar 32,85 yang diperoler dari hasil bagi antara keuntungan 
usaha dengan total biaya usaha ternak ayam broiler yang dinyatakan dalam persen.

Tabel 6. Rata-rata Efisiensi Usaha Ternak Ayam Broiler di Kecamatan Jumantono Kabupaten Karanganyar, Juni-Juli 2018

\begin{tabular}{llr}
\hline No. & Uraian & $\begin{array}{l}\text { Rata-rata } \\
\text { (Rp/siklus) }\end{array}$ \\
\hline 1 & Penerimaan (R) & 165.114 .558 \\
2 & Biaya Total (TC) & 124.291 .091 \\
& Efisiensi & 1,32 \\
\hline
\end{tabular}

Sumber: Analisis Data Primer (2018)

Tabel 6 menunjukkan Rata-rata Efisiensi Usaha Ternak Ayam Broiler di Kecamatan Jumantono Kabupaten Karanganyar pada Bulan Juni-Juli 2018. Efisiensi usaha ternak ayam broiler sebesar 1,32 yang diperoleh dari hasil bagi antara penerimaan dengan total biaya. Nilai R/C Rasio > 1 sehingga usaha tersebut dapat dikatakan layak untuk dijalankan.

Tabel 7. Rata-rata Break Event Point (BEP) Usaha Ternak Ayam Broiler di Kecamatan Jumantono Kabupaten Karanganyar, JuniJuli 2018

\begin{tabular}{lll}
\hline No. & \multicolumn{1}{c}{ Uraian } & \multicolumn{1}{c}{ Jumlah } \\
\hline 1 & BEP dalam penjualan & Rp 29.391.635 \\
2 & BEP dalam kuantitas & $1665,1 \mathrm{Kg}$ \\
3 & BEP dalam harga & Rp 13.489
\end{tabular}

Sumber: Analisis Data Primer (2018)

Tabel 7 menunjukkan rata-rata Break Event Point (BEP) Usaha Ternak Ayam Broiler di Kecamatan Jumantono Kabupaten Karanganyar pada Bulan Juni-Juli 2018. BEP dalam Penjualan sebesar Rp 29.391.635. BEP dalam Kuantitas sebesar 1665,1 Kg. BEP dalam Harga sebesar Rp 13.489. Break Event Point merupakan kondisi dimana suatu usaha tidak mendapat keuntungan maupun tidak mengalami kerugian.

Tabel 8. Analisis Resiko Usaha Ternak Ayam Broiler di Kecamatan Jumantono Kabupaten Karanganyar, Juni-Juli 2018

\begin{tabular}{llr}
\hline No. & \multicolumn{1}{c}{ Uraian } & \multicolumn{1}{c}{ Rata-rata } \\
\hline 1 & Keuntungan (E) & 40.823 .467 \\
2 & Simpangan baku & 3.473 .973 \\
& keuntungan (V) & 0,09 \\
3 & Koefisien Variasi (CV) & 33.875 .521 \\
4 & Batas bawah keuntungan & \\
\multicolumn{2}{l}{ Sumber: Analisis Data Primer (2018) }
\end{tabular}

Sumber: Analisis Data Primer (2018)
Berdasarkan tabel 8 dapat diketahui diketahui bahwa nilai $\mathrm{CV}<0,5$ dan nilai $\mathrm{L}>0$, artinya usaha ternak ayam broiler di Kecamatan Jumantono Kabupaten Karanganyar akan terhindar dari peluang kerugian yang ditunjukkan nilai CV sebesar 0,09. Dapat dilihat juga dari batas bawah keuntungan usaha ternak ayam broiler dimana menunjukkan positif (+) atau lebih dari nol (0).

\section{Analisis Usaha Tani}

Biaya merupakan nilai dari seluruh korbanan yang dikeluarkan dalam proses produksi. Biaya total merupakan penjumlahan dari biaya tetap dan biaya variabel. Rata-rata biaya total usaha ternak ayam broiler di Kecamatan Jumantono Kabupaten Karanganyar sebesar Rp 124.291.091 per siklus panen. Penerimaan usaha ternak ayam broiler di Kecamatan Jumantono Kabupaten Karanganyar rata-rata sebesar Rp 165.114.558 per siklus panen. Ratarata keuntungan usaha ternak ayam broiler di Kecamatan Jumantono Kabupaten Karanganyar sebesar Rp 40.823.467,- dengan tingkat profitabilitas $32,85 \%$. Profitabilitas merupakan hasil bagi antara keuntungan usaha dengan total biaya usaha ternak ayam broiler yang dinyatakan dalam persen.

Efisiensi Usaha. Efisiensi usaha dapat dilihat dari besarnya nilai R/C rasio yaitu perbandingan antara penerimaan dengan biaya total usaha ternak ayam broiler di Kecamatan Jumantono Kabupaten Karanganyar. Nilai yang diperoleh lebih dari satu, maka usaha dapat dikatakan layak untuk dijalankan, namun sebaliknya jika nilai yang diperoleh kurang dari satu maka usaha tidak layak untuk dijalankan. Efisiensi usaha ternak ayam broiler di Kecamatan Jumantono Kabupaten Karanganyar sebesar 1,32 yang artinya usaha ternak ayam broiler layak untuk dijalankan. Nilai R/C ratio sebesar 1,32 yang artinya setiap Rp 1,- biaya yang dikeluarkan untuk usaha ternak ayam broiler di Kecamatan Jumantono Kabupaten Karanganyar akan menghasilkan penerimaan sebesar Rp 1,32,00.

\section{Break Event Point}

Dari nilai BEP diketahui pada tingkat produksi dan harga berapa suatu usaha tidak memberikan keuntungan dan tidak pula mengalami kerugian. Rata-rata Break Event Point (BEP) dalam penjualan usaha ternak 
ayam broiler di Kecamatan Jumantono Kabupaten Karanganyar sebesar $\mathrm{Rp} \quad \mathrm{Rp}$ 29.391.635,00 selanjutnya Break Event Point (BEP) dalam kuantitas sebesar $1.665,1 \mathrm{~kg}$ dan Break Event Point (BEP) dalam harga sebesar Rp 13.489.

\section{Analisis Resiko}

Risiko usaha pada usaha ternak ayam broiler di Kecamatan Jumantono Kabupaten Karanganyar merupakan kemungkinan merugi yang dihadapi peternak ayam broiler dalam menjalankan usahanya. Resiko muncul dari berbagai sumber dan adanya ketidakpastian. Namun kemungkinan adanya resiko tersebut dapat diketahui dengan menggunakan pendekatan perhitungan koefisien variasi $(\mathrm{CV})$ dan batas bawah keuntungan $(\mathrm{L})$. Koefisien variasi $(\mathrm{CV})$ merupakan perbandingan antara resiko yang harus ditanggung dengan jumlah keuntungan yang akan diperoleh. Sedangkan batas bawah keuntungan menunjukkan nilai nominal keuntungan terendah yang mungkin diterima peternak. Resiko usaha ternak ayam broiler dan batas bawah keuntungan usaha ternak ayam broiler di Kecamatan Jumantono Kabupaten Karanganyar dapat dilihat pada Tabel 8. Dapat diketahui bahwa Usaha ternak ayam broiler di Kecamatan Jumantono Kabupaten Karanganyar memiliki batas bawah Rp 33.875.521 dan koefisien variasi $(\mathrm{CV})$ sebesar 0,09 . Nilai batas bawah keuntungan menunjukkan keuntungan minimum yang akan didapatkan oleh peternak ayam broiler. Berdasarkan dari uraian diatas diketahui bahwa nilai $\mathrm{CV}<0,5$ dan nilai $\mathrm{L}>$ 0 , artinya usaha ternak ayam broiler di Kecamatan Jumantono Kabupaten Karanganyar akan terhindar dari peluang kerugian yang ditunjukkan nilai CV sebesar 0,09. Dapat dilihat juga dari batas bawah keuntungan usaha ternak ayam broiler dimana menunjukkan positif $(+)$ atau lebih dari nol (0).

\section{KESIMPULAN DAN SARAN}

\section{Kesimpulan}

Berdasarkan hasil penelitian dan pembahasan yang telah diuraikan pada bab sebelumnya maka dapat diambil kesimpulan sebagai berikut:

1. Rata-rata biaya total yang dikeluarkan dalam usaha ternak ayam broiler di Kecamatan Jumantono Kabupaten Karanganyar sebesar
Rp 124.291.091. Sedangkan rata-rata jumlah penerimaan sebesar Rp 165.114.558. Ratarata keuntungan yang diperoleh usaha ternak ayam broiler sebesar Rp 40.823 .467 dengan profitabilitas sebesar 32,85\%. BEP (Break Event Point) berdasarkan hasil penjualan sebesar Rp 29.391.635. BEP (Break Event Point) berdasarkan kuantitas (produksi) sebanyak 1.665,1 kg. BEP (Break Event Point) berdasarkan harga sebesar Rp 13.489 per $\mathrm{kg}$.

2. Efisiensi usaha ternak ayam broiler di Kecamatan Jumantono Kabupaten Karanganyar sebesar 1,32 yang berarti usaha tersebut layak untuk dijalankan. 3) usaha ternak ayam broiler mempunyai nilai $\mathrm{CV}<$ 0,5 atau $\mathrm{L}>0$ sehingga usaha ternak ayam broiler di Kecamatan Jumantono Kabupaten Karanganyar terhindar dari resiko, karena jika dilihat dari batas bawah keuntungan menunjukkan nilai positif.

\section{Saran}

Berdasarkan penelitian dan hasil analisis yang dilakukan oleh peneliti maka saran yang diberikan yaitu:

1. Peternak sebaiknya lebih selektif dalam memilih poultry shop (perusahaan), yaitu peternak dapat kerjasama dengan mitra perusahaan yang menawarkan harga sarana produksi yang rendah sehingga dapat meningkatkan efisiensi usaha ternak.

2. Peternak ayam broiler sebaiknya meningkatkan hasil usaha dengan menambah jumlah Day Old Chick (bibit) yang di usahakan.

\section{DAFTAR PUSTAKA}

Antriyandarti, E. 2012. Ekonomika Mikro untuk Ilmu Pertanian. Yogyakarta: Nuha Litera.

Loen. (2017/08/22). Kelebihan Ayam Broiler dan Kekurangan Beternak Ayam Broiler atau Ayam Pedaging. Retrieved from http://www.habaloen.com/2017/03/keleb ihan-ayam-broiler-dan-kekurangan.html.

Kadarsan.1995. Keuangan Pertanian dan Pembiayaan Perusahaan Agribisnis. Jakarta: PT Gramedia Pustaka Utama. 
Himmah N. H., Minar Ferichani, Isti Khomah: Analisis Usaha Ternak Ayam Broiler...

Wandi. (2015/11/02). Peranan Bidang Peternakan Dalam Upaya Meningkatkan Kesejahteraan Rakyat. Retrieved from http://celahkotanews.com.

BPS SUSENAS. (2017/01/20). Statistik Peternakan dan Kesehatan Hewan. Direktorat Jenderal Peternakan dan Kesehatan Hewan, Kementerian Pertanian. Retrieved from http://ditjenpkh.go.id.

Singarimbun, M dan S. Effendi. 1995. Metode Penelitian Survei. Jakarta: LP3ES.
Surakhmad, W. 2001. Pengantar Penelitian Ilmiah: Dasar, Metode, dan Teknik. Bandung: Penerbit Tarsito.

Soekartawi. 1995. Analisis Usaha Tani. Jakarta: UI Press.

Suratiyah, K. 2015. Ilmu Usaha Tani (Edisi Revisi). Jakarta: Penebar Swadaya.

Hernanto, F. 1993. Ilmu Usaha Tani. Jakarta: Penebar Swadaya. 